\title{
Impact of osmotic dehydration on the encapsulated apices survival of two yams (Dioscorea spp.) genotypes from Benin
}

Arnaud AGBIDINOUKOUN ${ }^{*}$, Corneille AHANHANZO1, Hubert ADOUKONOU-SAGBADJA ${ }^{1}$, Majid ADJASSA ${ }^{1}$, Micheline AGASSOUNON DJIKPO-TCHIBOZ0'1, Clément AGBANGLA1.

${ }^{1}$ Laboratoire de Génétique et des Biotechnologies, Faculté des Sciences et Techniques (FAST), Université d'AbomeyCalavi (UAC), 01BP 526 Cotonou, Bénin.

*Author for correspondence: arnaudag2002@yahoo.fr; Tel: +22995152375

Original submitted in on $6^{\text {th }}$ May 2013 Published online at www.m.elewa.org on 29th May 2013.

http://dx.doi.org/10.4314/iab.v65i0.89642

\begin{abstract}
Objective: Cryopreservation is one of the biotechnological methods currently used for long term conservation of plant genetic resources. It requires many steps such as a pretreatment, which involves cells dehydration in order to make them tolerant to desiccation and freezing in nitrogen liquid using high sucrose concentration. The present study aims to establish a protocol for long term conservation of yam germplasm in Benin using encapsulation/dehydration technique.

Methodology and Results: The effects of different sucrose concentrations and immersion durations on encapsulated apices of two yams genotypes (Da93G1 from Dioscorea alata and Dcr164 from complex Dioscorea cayenensis/D. rotundata) were tested. The apices were excised from six months old vitroplants on stereoscope and transferred in M1 medium (MS+2g.L-1 activated charcoal) prior to encapsulation in alginate $(3 \%)$ beads with calcium chloride $(1.32 \mathrm{M})$. Then, the apices were exposed to osmotic dehydration with two concentrations of sucrose $(0.75 \mathrm{M}$ and $1.25 \mathrm{M})$ at two durations ( $24 \mathrm{~h}$ and $40 \mathrm{~h}$ ) before their culture in $\mathrm{M} 2 \mathrm{medium}$

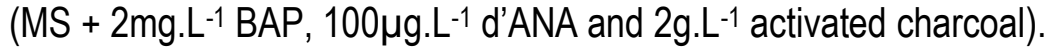

Conclusion and application: The results showed that $0.75 \mathrm{M}$ sucrose increased high survival rate $(80 \%)$ and high rate of regenerated plant $(70 \%)$ at $24 \mathrm{~h}$ of immersion duration. Furthermore, significant difference was observed between the two genotypes response. This work has allowed adopting in further experiments $0.75 \mathrm{M}$ sucrose and 24hours of immersion duration in pretreatment of yam apices for the development of cryopreservation techniques for yam conservation in Benin.
\end{abstract}

Keywords: Dioscorea spp., sucrose, osmotic dehydration, regeneration, immersion duration, cryopreservation, Benin.

\section{INTRODUCTION}

Yam belongs to the genus Dioscorea (Dioscoreaceae). The genus contains about 600 species with more than 10 species cultivated for food and for pharmaceutical purposes (Coursey, 1976; Aké Assi, 1998). Six species of them are more important: white yam (Dioscorea rotundata), water yam (Dioscorea alata), yellow yam (Dioscorea cayenensis), trifoliate or bitter yam (Dioscorea dumetorum), aerial yam (Dioscorea bulbifera) and Chinese yam (Dioscorea esculenta) ( $\mathrm{Ng}$ and $\mathrm{Ng}$ 
1994). In West Africa, and particularly in Benin, yam is one of the staple food crops contributing to food security and poverty reduction. In addition to its economic and nutritional values, there is a preeminent socio-cultural dimension of the use of yam across most of the sociolinguistic groups in Benin (Dansi et al. 2000, Zannou et al. 2009).

In the whole farming system, the conservation of yam genetic resources remains the main challenge to take up. Indeed, traditionally, yam germplasm are maintained in field genebanks as living collections because genotypes are either highly sterile, produce heterogeneous seeds, or possess tubers which have poor storability (Zoundjihekpon 1993, Mandal et al. 1996). Since yam is predominantly vegetatively propagated, conservation of its germplasm using conventional method of field maintenance poses various problems. Field maintenance involves high costs and important post-harvest lost due to pest/pathogen attacks and natural disasters (Mandal et al. 2007, Houedjissin et al. 2010). Without an efficient technique of conservation, there is an important risk of genetic erosion of yam genetic resources. It is important to find out an alternative way for best storability of the yam genotypes. In vitro plant tissue and organ culture can be an alternative way to solve this problem (Ahanhanzo et al. 2010). However, the maintenance of large in vitro collections is time consuming and the risks of contamination and somaclonal variation increase with time (Podwyszyńska, 2005). Cryopreservation techniques presently offer the most promising

\section{MATERIEL AND METHODS}

Biological material: Two yams genotypes (accession Dcr164 belonging to the complex Dioscorea cayenensis/D. rotundata and accession Da93G1 belonging to the species Dioscorea alata) were used in this study. These genotypes were collected at the in vitro genebank of the Laboratory of Genetic and Biotechnology of the Faculty of Sciences and Techniques (University of Abomey-Calavi, Republic of Benin). The choice of these two accessions is guided by the fact that their tubers are more sensible to pest/pathogen attacks. In addition, they are well adapted to microcutting response.

Methods

Preparation of microshoots for encapsulation: Microshoots were obtained from six months old approach for long term conservation of germplasm under conditions favouring high genetic stability and minimal maintenance requirements (Mandal et al. 1996, Engelmann et al. 2000). Various cryopreservation techniques have been developed and protocols have been established for several plant species such as Yam (Mandal et al. 1996, 2007), Elaeis guineensis (Engelmann, 1995), Solenostemon rotundifolius (Nino et al. 2000), Pelargonium (Dumet, 2002, Gallard, 2008), Musa (Panis, 2009), Manihot esculenta Crantz (Dumet, 2011). According to the available literature, two techniques are reported to be successfully for cryopreservation (droplet vitrification and encapsulation/dehydration).

Encapsulation/dehydration method is critically dependent upon the optimization of dehydration and meristems desiccation tolerance is an important survival factor (Barbara et al. 2001). On top of that, the transfer of cryopreservation protocols from one laboratory to another may result in variable responses, reflecting differences of physiological status of the cultures in response to desiccation or culture conditions (Barbara et al. 2001).Thus far, in Benin, cryopreservation has not yet been applied in research programs. The aim of this study was to establish a protocol for long term conservation of yam germplasm in Benin using encapsulation/dehydration technique. To this end, the effects of different sucrose concentrations and immersion durations on encapsulated apices of two yams genotypes were tested.

vitroplants and cultivated two weeks in Petri dishes containing semi-solid Murashige and Skoog (1962) medium (MS) supplemented with $2 \mathrm{~g} \cdot \mathrm{L}^{-1}$ activated charcoal. Each Petri dish contained about 45 at 50 microshoots.

Apices excision: The apices were excised from auxiliary buds of microshoots after two weeks culture in sterile condition over laminar flow. The excision was made on stereoscope using sterile scalpel blade $\mathrm{N}^{\circ} 11$. Then, the apices were laid on semi-solid hormone-free MS medium supplemented with $100 \mathrm{~g}$ sucrose, $7 \mathrm{~g}$ bacteriological agar and $2{\mathrm{~g} . \mathrm{L}^{-1}}^{-1}$ activated charcoal (M1 medium) and were left one day in the dark at $25^{\circ} \mathrm{C}$. 
Encapsulation of apices and immersion in sucrose solution: The apices were moved in alginate sodium $(3 \%)$ and were dropped in polymerization solution (calcium chloride 1.32M) in order to develop the beads, which contained one apex each. The beads were dry out on sterile filter paper before their immersion in high sucrose solution ( $0.75 \mathrm{M}$ and $1.25 \mathrm{M}$ ) during 24 hours and 40 hours over agitation (100rpm). After exposing on high sucrose, the apices were grow in Petri dishes on semi-solid MS medium supplemented with $2 \mathrm{mg}^{-\mathrm{L}^{-1} \mathrm{BAP}}$, $100 \mu \mathrm{g} \cdot \mathrm{L}^{-1}$ NAA and 2g.L-1 activated charcoal (M2 medium). Each dish contains 10 encapsulated apices as showed in Table1. All media were sterilized for $15 \mathrm{~min}$ at $115^{\circ} \mathrm{C}$ and the $\mathrm{pH}$ was adjusted to 5.7 before sterilization. The dishes with encapsulated apices were maintained in dark for one week then transferred to fluorescent light $\left(5.000 \mu \mathrm{mol} . \mathrm{m}^{-2} . \mathrm{S}^{-1}\right)$ for $16 \mathrm{~h}$ per day at $27 \pm 1^{\circ} \mathrm{C}$. The apices were cultured for 8 weeks and the following parameters were evaluated:

- $\quad$ The survival rate was assessed three weeks after culture in M2 medium by counting the number of growing apices. An apex was considered alive when it was green.

- $\quad$ The necrosis rate was determined three weeks after culture in M2 medium by counting the number of necrosis apices which appeared totally brown, not hairy and showed no sign of regrowth.

- $\quad$ The regenerated rate was expressed by a percentage of a total of growing apices forming shoots and roots within 8 weeks.

- $\quad$ The callus rate was determined three weeks after culture in M2 medium by counting the number of apices producing callus on the scar zone.

Table1. Treatments of the encapsulated apices of the two tested yam accessions

\begin{tabular}{lll}
\hline $\begin{array}{l}\text { Treatments } \\
\text { (Concentration of sucrose }+ \text { immersion duration) }\end{array}$ & $\begin{array}{l}\text { Number of encapsulated apices per } \\
\text { Accession }\end{array}$ \\
\cline { 2 - 3 } & Da93G1 & Dcr164 \\
\hline T1: $0.75 \mathrm{M}+24 \mathrm{~h}$ & 10 & 10 \\
$\mathrm{~T} 2: 1.25 \mathrm{M}+24 \mathrm{~h}$ & 10 & 10 \\
$\mathrm{~T} 3: 0.75 \mathrm{M}+40 \mathrm{~h}$ & 10 & 10 \\
$\mathrm{~T} 4: 1.25 \mathrm{M}+40 \mathrm{~h}$ & 10 & 10 \\
\hline
\end{tabular}

Experimental design: To test the effect of the different treatments, treatments were plotted in a completely randomized design with two replicates. Each treatment included 20 apices (10 apices per accession). The data

\section{RESULTS}

Response of encapsulated apices: The Figure 1 illustrates the response of encapsulated apices to different treatments. After two to eight weeks of culture, four various reactions were noticed:

- Browning apices indicating that the apices were immediately dead by the tissues necrosis, were analyzed using SAS program version 9.0 and if ANOVA indicated significant $(P<0.05)$ differences, the means (expressed as percentage) were separated using Student, Newman and Keuls' test.

- Swelling apices which were still green indicating activated cells multiplication,

- Callus production,

- and cells differentiation to produce shoots. 

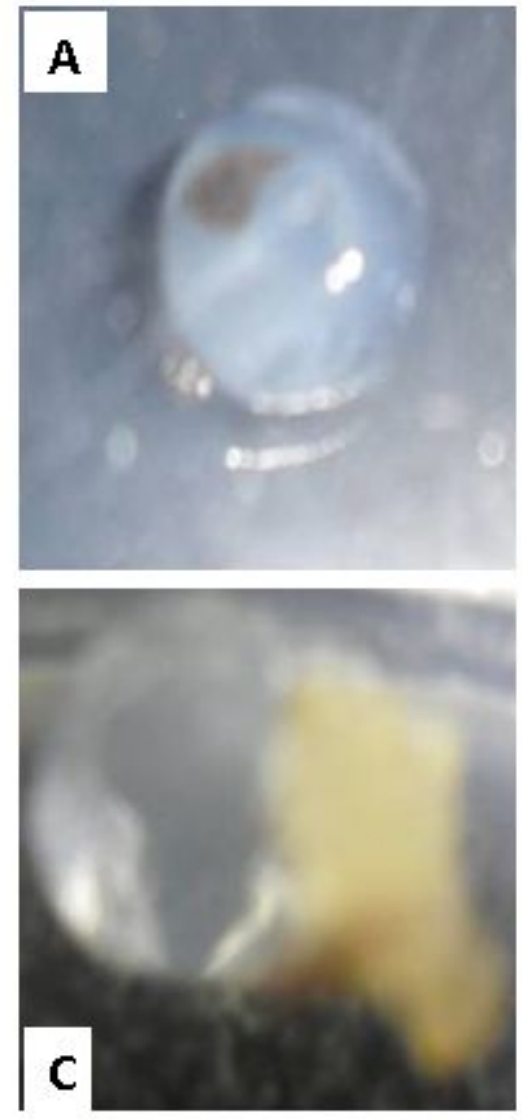
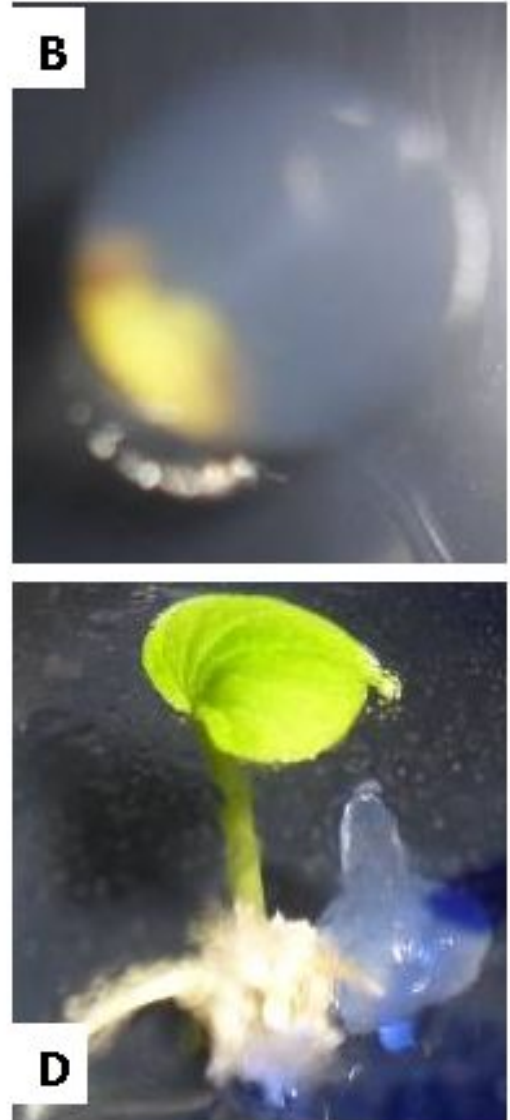

Figure 1: Reaction of encapsulated apices after sucrose (0.75M) treatment (from accession Da93G1) A- Necrosis apex ; B-swelling apex ; C- Callus apex ; D- Regenerated apex

Effect of sucrose concentration and immersion duration on apices survival: Most of the encapsulated apices treated from $0.75 \mathrm{M}$ sucrose survived (treatments 1 and 3) within 2 weeks independently to immersion duration (Figure1a). The high level of survival (90\%) was obtained from the accession Dcr164, but was not significantly different compared to accession Da93G1 $(70 \%)$. In contrast, most of the apices which were exposed in 1.25M sucrose dead (treatments 2 and 4). Besides, the long immersion duration increased the death rate of apices (Figure1b). When the apices were exposed during 40 hours in $1.25 \mathrm{M}$ (T4), the high survival rate was $20 \%$ with both of accessions while this rate ranged from 20\% (Dcr164) to 50\% (Da93G1) with 24 hours in the same sucrose concentration (T2) with significant difference between accessions. On the other hand, the media containing high sucrose $(1.25 \mathrm{M})$ increase mostly necrosis apices (treatments $\mathrm{T} 1$ and T2) compared to those media that have less sucrose $(0.75 \mathrm{M})$ according to treatments T1 and T3 (Figure1b). Furthermore, maximal necrosis apices rate $(80 \%)$ was unregistered in treatment T4 

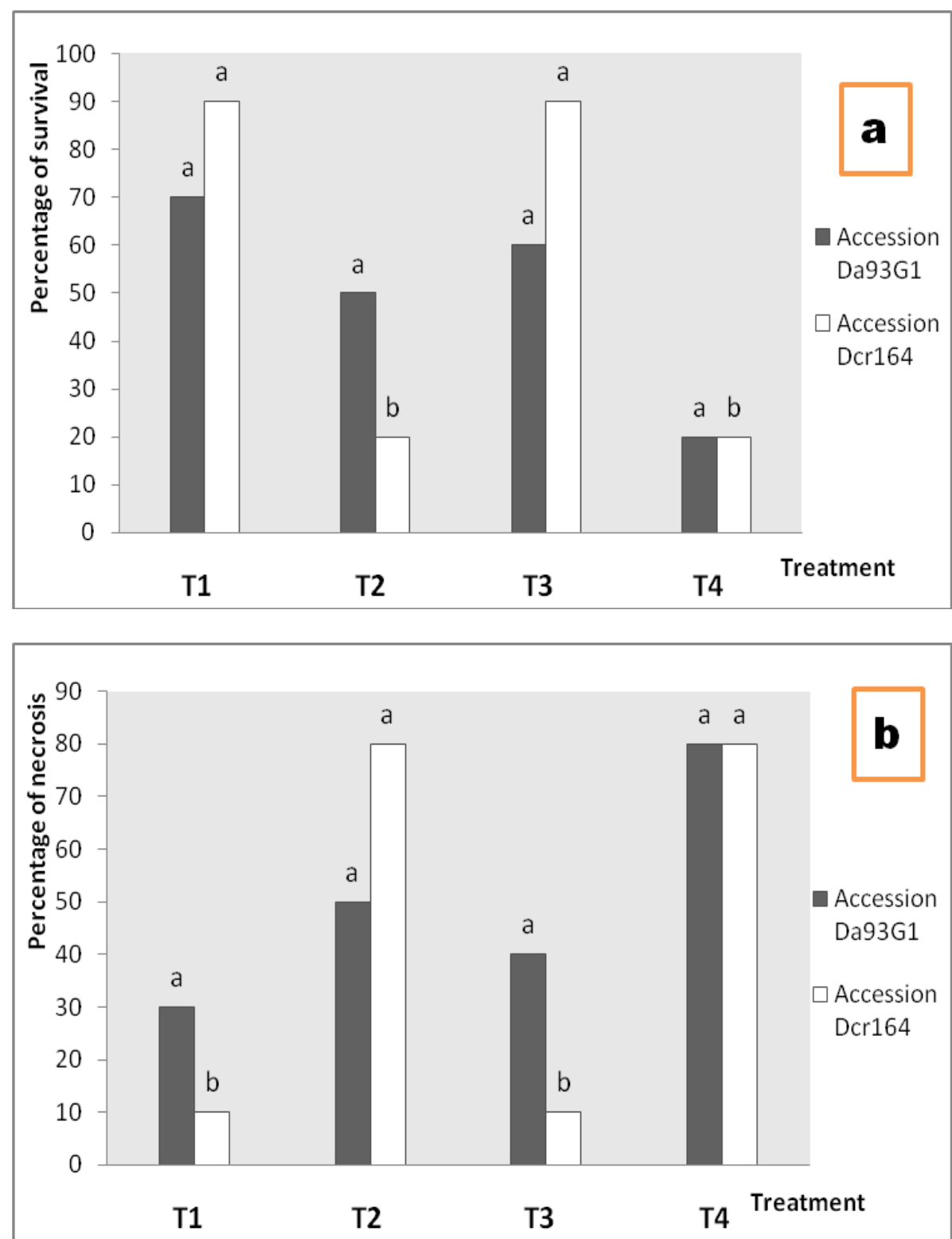

Percentages in the same color followed by the same letters do not differ significantly $(p<0.05)$.

Figure 2: Survival (a) and necrosis (b) rates of yam apices in the different treatments.

Effect of sucrose concentration and immersion duration on callus induction: Callus was observed within two weeks after apices culture in M2 medium. Irrespective of treatments, none of the apices of the accession Da93G1 had callus (Table 2). However, callus proliferation was noticed on apices belonging to accession Dcr164, which show the highest percentage of callus. Furthermore, a high sucrose concentration increased callus formation $(80 \%$ with $1.25 \mathrm{M}$ sucrose against $20 \%$ with $0.75 \mathrm{M})$. Significant difference $(P<0.001)$ was observed with the effect of immersion duration on callus induction. Proportion of callus ranged from $0 \%$ to $20 \%$ respectively after a 24 hours and 40 hours immersion in $0.75 \mathrm{M}$ sucrose. Similar observations were noticed with $1.25 \mathrm{M}$ sucrose. Overall, an average of callus (80\%) was observed after 40 hours against $50 \%$ after 24 hours. 
Table 2: Effect of different treatments on callus formation of the two tested yam accessions

Treatments

(Concentration of sucrose + immersion duration)

Callus rate (\%)

\begin{tabular}{|c|c|c|}
\hline & Da93G1 & Dcr164 \\
\hline $\mathrm{T} 1: 0.75 \mathrm{M}+24 \mathrm{~h}$ & $0^{a}$ & $0^{c}$ \\
\hline $\mathrm{T} 2: 1.25 \mathrm{M}+24 \mathrm{~h}$ & $0^{a}$ & $50^{a b}$ \\
\hline $\mathrm{T} 3: 0.75 \mathrm{M}+40 \mathrm{~h}$ & $0^{a}$ & $20^{\mathrm{bc}}$ \\
\hline $\mathrm{T} 4: 1.25 \mathrm{M}+40 \mathrm{~h}$ & $0^{a}$ & $80^{a}$ \\
\hline
\end{tabular}

Percentages in the same row followed by the same letters do not differ significantly $(p<0.05)$.

Effect of sucrose concentration and immersion duration on regeneration: The Table 3 shows the regeneration of apices on different treatments within 8 weeks culture. The results indicate that the accession Da93G1 (Dioscorea alata) has the highest percentage of regeneration $(70 \%)$ with $0.75 \mathrm{M}$ sucrose treated for 24hours (treatment 1 ) while the $1.25 \mathrm{M}$ sucrose treatment induced only slightly regeneration of apices $(10 \%)$ at equal immersion during (treatment 2). None of the apices belonging to accession Dcr164 was regenerated when the sucrose concentration is important (1.25M).On the other hand, results indicated that, a long duration exposition decreased the regeneration of apices. In fact, with $1.25 \mathrm{M}$ sucrose, $10 \%$ of apices belonging to accession Da93G1 were regenerated after 24hours immersion (T2) while none of them was regenerated after 48 hours exposition (T4). The Figure 3 shows the pictures of regenerated apices and non-regenerated apices.

Table 3: Effect of different treatments on regeneration of the two tested yam accessions

\section{Treatments}

(Concentration of sucrose + immersion duration)

\section{Regeneration level (\%)}

\begin{tabular}{lll}
\cline { 2 - 3 } & Da93G1 & Dcr164 \\
\hline $\mathrm{T} 1: 0.75 \mathrm{M}+24 \mathrm{~h}$ & $70^{\mathrm{a}}$ & $20^{\mathrm{a}}$ \\
$\mathrm{T} 2: 1.25 \mathrm{M}+24 \mathrm{~h}$ & $10^{\mathrm{b}}$ & $0^{\mathrm{a}}$ \\
$\mathrm{T} 3: 0.75 \mathrm{M}+40 \mathrm{~h}$ & $20^{\mathrm{b}}$ & $10^{\mathrm{a}}$ \\
$\mathrm{T} 4: 1.25 \mathrm{M}+40 \mathrm{~h}$ & $0^{\mathrm{b}}$ & $0^{\mathrm{a}}$ \\
\hline
\end{tabular}

Percentages in the same row followed by the same letters do not differ significantly $(p<0.05)$.

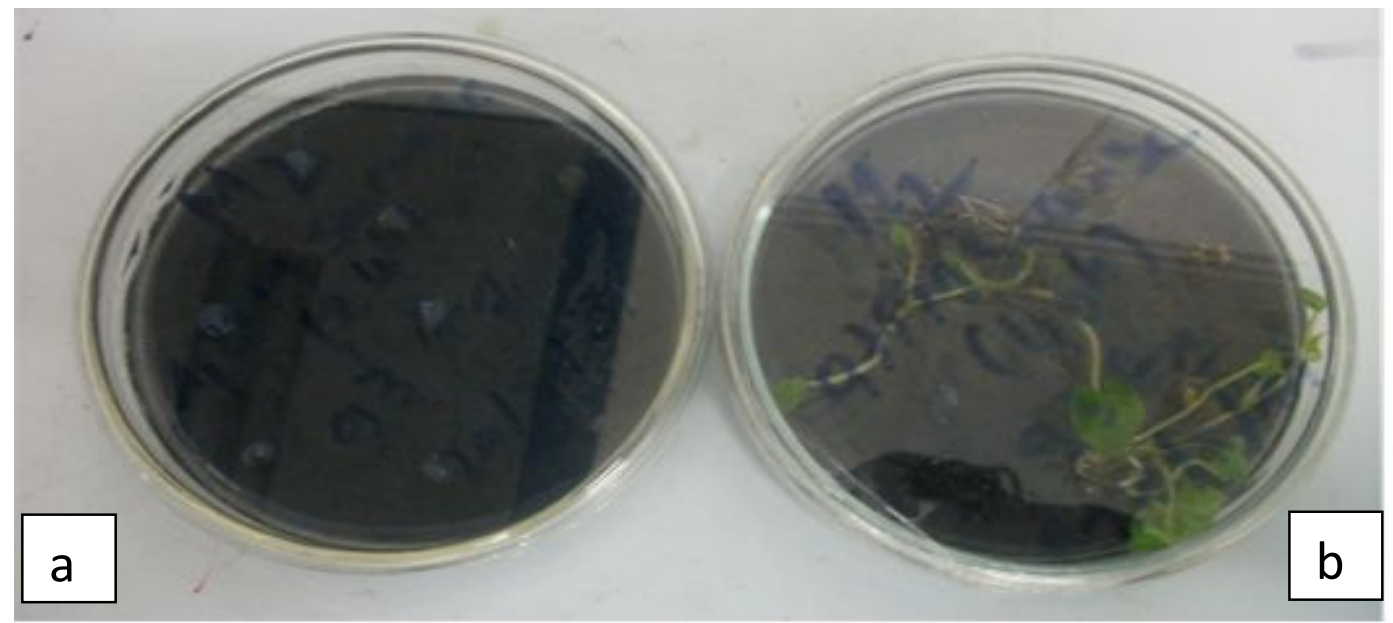

Figure 3: Apices response belonging to accession Da93G1

(a) $=$ non-regenerated apices, $b=$ regenerated apices.

\section{DISCUSSION}

Several studies showed that the level of water in alginate beads is an important factor for survival of encapsulated apices. Consequently, an important water in beads induce lethal ices after freezing in liquid nitrogen who 
damage cells while low water induce high dehydration and subsequently the cells death (Baudot et al, 1998). The results obtained in this experiment showed that the accession Dcr164 (Dioscorea cayenensis) recorded the highest rate of survival $(90 \%)$ with $0.75 \mathrm{M}$ sucrose while Da93G1 accession (Dioscorea alata) presented 70\%. Despite the fact that no statistical difference was observed between them, the survival rates of apices varied with sucrose concentration and the genotype (treatment 2). These results are congruent with previous reports on Pelargonium species which illustrated genotypic differences (survival and regeneration rates) in response to cryopreservation protocols Gallard (2008). Dumet et al (2011) also showed that Manihot meristems surviving cryopreservation depends on accessions.

With regards to sucrose molarity, $0.75 \mathrm{M}$ sucrose increased high level survival comparing to $1.25 \mathrm{M}$ sucrose. This result supports Dumet et al (2002) who reported that $0.75 \mathrm{M}$ sucrose molarity optimizing tolerance to desiccation and cryopreservation of numerous plant tissues. The high rate of apices death could be explained by the excessive osmotic dehydration induces by high concentration of the sucrose which causes cells plasmolyze (Finkle et al. 1985). According to Stranzel et al (1988), the process of sucrose accumulation depends on its concentration in the medium: at concentrations lower than $10^{-3} \mathrm{M}$, sucrose was hydrolyzed before absorption whereas at higher concentrations, sucrose uptake proceeded through hydrophilic membrane

\section{CONCLUSION}

The present study defined the optimal conditions for the pretreatment of yam apices of two Beninese genotypes prior to the freezing in nitrogen liquid. Before their immersion in nitrogen liquid, at ultra low temperature, cells need to be devoid of intracellular liquid in order to avoid lethal ices formation, which is prejudicial to their

\section{REFERENCES}

Ahanhanzo C, Gandonou CB, Agbidinoukoun A, Dansi A, Agbangla C, 2010. Effect of two cytokinines in combination with acetic acid a-naphthalene on yams (Dioscorea spp.) genotypes' response to in vitro morphogenesis. African journal of Biotechnology vol. 9(51), pp. 8837-8843.

Ahouanse KB, 1996. Contribution à la mise au point d'une technique de culture in ovulo d'embryons globulaires de Phaseolus Vulgaris L. Pour l'obtention du Certificat d'études Approfondies en Sciences Agronomiques à la FSA/UNB, Abomey-Calavi; 100p. domains. They further noticed that sucrose appears to have a very specific action for the acquisition of tolerance to freezing in liquid nitrogen with tissues at intermediate water contents. Intracellular concentration of sucrose may be sufficient to protect cell structures, either by allowing vitrification of intracellular solutes at positive temperature (Williams and Leopold, 1989) or by stabilizing membranes and proteins (Crowe and Crowe, 1986).

Based on the present results, callus induction depends in large part on genotype and less evidently on high sucrose concentration. However, the mechanism of callus induction is still poorly understood. The regeneration capacity of both accessions tested varied with different treatments. Similar results were reported on cryopreservation of Pelargonium cultivars indicating that only cultivar 'Balcon Lilas' developed best aptitude to regenerate after encapsulation/dehydration in contrast to others cultivars which apices induced callus with hyperhydric shoots (Gallard, 2008). Ahouanse (1996) also showed that the number of germinated embryos of Phaseolus Vulgaris L. decreased with high sucrose concentration in the media. In contrast, Engelmann (1995) noticed that an additional pregrowth treatment of embryos on a medium with high sugar concentration may also prove beneficial to increase the resistance of embryos to desiccation and freezing. Therefore, the response of the increase of osmotic pressure may be species

specific.

survival and regeneration. This work permits to adopt in the further experiment $0.75 \mathrm{M}$ sucrose and 24hours of immersion duration in pretreatment of yam apices for the development of cryopreservation techniques for yam conservation.

Aké Assi L, 1998. La diversification des utilisations des ignames: usage pharmaceutique traditionnel. In: Berthaud J, Bricas N, Marchand J-L (eds) L'Igname, Plante Séculaire et Culture d'Avenir. Actes du Séminaire International, 3-6 Juin 1997, Montpellier, France. Centre de Coopération Internationale en Recherche Agronomique pour le Développement (CIRAD), Montpellier, pp. 263-273.

Barbara MB, Dumet D, Denoma JM, Benson EE, 2001. Validation of cryopreservation protocols for plant germplasm conservation: a pilot study using 
Ribes L. biodiversity and Conservation 10, 939 949

Baudot A, Mazuer J, Odin J, 1998. Cryopreservation : conserver des éléments biologiques par vitrification, Rev. Gén. Froid. N 981, p 35

Coursey DG, 1976. Yams, Dioscorea spp. (Dioscoreaceae). In: Simmonds NW (Ed) Evolution of Crop Plants. Longman, London, pp. 70-74

Crowe JH. and Crowe LM, 1986. Stabilization of membranes in anhydrobiotic organisms. in Leopold A.E. (Ed.) Membranes, metabolism and $d$ y organisms. Ithaca, New York, Comstock Publishing Associates. pp 188-209.

Dansi A, Mignouna HD, Zoundjihékpon J, Sangaré A, Asiedu R, Ahoussou N, 2000. Using isozyme polymorphism to assess genetic variation within cultivated yam (Dioscorea cayenensis / Dioscorea rotundata complex) of the Republic of Benin. Gen. Res. Crop Evol. 47: 371-383

Dumet D, Engelmann F, Chabrillange N, Dussert $S$, Duval Y, 1994. Effect of various sugars and polyols on the tolerance to desiccation and freezing of oil palm polyembryonic cultures. Seed Science Research 4, 307-313

Dumet D, Grapin A, Bailly C, Dorion N, 2002. Revisiting crucial of an encapsulation/desiccation based cryopreservation process: importance of thawing method in the case of pelargonium meristems. Plant Science 163, 1121- 1127.

Dumet D, Korie S, Adeyemi A, 2011. Cryobanking cassava germplasm at IITA. Acta Hort. (ISHS) 908:439-446

http://www.actahort.org/books/908/908_56.htm

Engelmann F, Chabrillange N, Dussert S, Duval $\bar{Y}, 1995$. Cryopreservation of zygotic embryos and kernels of oil palm (Elaeis guineensis Jacq.), seed Science Research 5, 81-86 81

Engelmann F. and Takagi H, 2000. Cryopreservation of tropical plant germplasm - current research progress and applications. Tsukuba: JIRCAS; Rome: IPGRI

Engelmann F, 2004. Plant cryopreservation: progress and prospects. In Vitro Cell. Dev. Biol. - Plant 40:427-433

Finkle BJ, Zavala ME, Ulrich JM, 1985. Cryoprotective compounds in the viable freezing of plant tissues. in Kartha, K.K. (Ed.) Cryopreservation of plant cells and organs, CRC Press, Boca Raton, Florida. pp 75-114
Gallard A, 2008. Etude de la cryoconservation d'apex en vue d'une conservation a long terme de collections de ressources génétiques végétales: compréhension des phénomènes mis en jeu et évaluation de la qualité du matériel régénère sur le modèle pelargonium, thèse de doctorat, école doctorale d'Angers. 112p

Houedjissin RC. and Koudande DO, 2010. Etat des lieux de la recherche sur l'igname au Bénin, rapport final, $55 p$

Mandal BB, Chandel KPS, Dwivedi S, 1996. Cryopreservation of yam (Dioscorea spp) shoots apices by encapsulation-dehydration. Cryo Letters 17. 165-174

Mandal BB. and Sonali DS, 2007. Cryopreservation of in vitro shoot tips of Dioscorea deltoidea Wall., an endangered medicinal plant: effect of cryogenic procedure and storage duration. Cryo Letters 28 (6), 461-470

Murashige T. and Skoog E, 1962. A revised medium for rapid growth and bioassays with tobacco tissue cultures. Physiologia Planfarum 15,473-497

$\mathrm{Ng} \mathrm{NQ}$. and Ng SYC, 1994. Approaches for germplasm conservation. In: Akoroda MO (ed.), Root crops for food security in Africa. Proceedings of the 5th Symposium of the International Society for Tropical Root Crops - Africa Branch, Kampala, Uganda, 22-28 November 1992. International Society for Tropical Root Crops (ISTRC), Africa Branch, Kampala, Uganda, pp. 135-140

Niino T, Hettiarachchi A, Takahashi J, Samarajeewa PK. 2000. Cryopreservation of lateral buds of in vitro rown innala plants (Solenostemon rotundifolius) byvitrification. Cryo Letters, 21(6): 349-356

Panis $B, 2009$. Cryoconservation de matériel génétique de bananier: 2ème édition. Guides techniques No. 9 (F. Engelmann et E. Benson, eds). Bioversity International, Montpellier, France

Podwyszyńska M, 2005. Somaclonal variation in micropropagated tulips based on phenotype observation. Journal of Fruit and Ornamental Plant Research, Vol. 13: 109-122

Stranzel M, Sjolund RD, Komor E, 1988. Transport of glucose, fructose and sucrose by Streptanthis tortuosus suspension cells. I. Uptake at low sugar concentrations. Planta 174, 201-209

Williams RJ. and Leopold AC, 1989. The glassy state in com embryos. Plant Physiology 89,977-981

Zannou A, Agbicodo E, Zoundjihékpon J, Struik PC, Ahanchédé A, Kossou DK, Sanni A, 2009. Genetic variability in yam cultivars from the 
Guinea- Sudan zone of Benin assessed by random amplified polymorphic DNA, African Journal of Biotechnology Vol. 8 (1), 026-036

Zoundjihékpon J, 1993. Biologie de la reproduction et génétique des ignames cultivées de l'Afrique de I'Ouest, Dioscorea cayenensis/ D. rotundata. Thèse de Doctorat d'Etat, Université Nationale de Côte d'Ivoire. p. 306. 